Ethiopian Journal of Environmental Studies \& Management 10(4): 520 - 529, 2017.

ISSN:1998-0507

doi: https://dx.doi.org/10.4314/ejesm.v10i4.9

Submitted: February 01, 2017

Accepted: June 01, 2017

\title{
WATER QUALITY ASSESSMENT OF HAND-DUG WELL IN SABON-GARI, ZARIA, NIGERIA
}

\author{
*YAKUBU, S., ${ }^{1}$ BELLO, A.O. ${ }^{2}$ AND DIYAJI, R.D. ${ }^{2}$ \\ ${ }^{1}$ Department of Geography, Osun State University Osogbo, Nigeria \\ ${ }^{2}$ Department of Geography, Federal College of Education Zaria, Nigeria
}

\begin{abstract}
This study examined the quality of hand-dug wells in Sabon-Gari area of Zaria, Nigeria. Three sets of sampled hand dug-wells were used for the study. They are small, medium and large wells classified based on their diameter. Water samples were collected from twenty-seven (27) different wells at strategic locations in the city to ascertain suitability of water from the well for human consumption with little or no treatment. The physicochemical and micro-biological parameters assessed include $\mathrm{pH}$, temperature, dissolved oxygen (DO) biochemical oxygen demand (BOD), total hardness, dissolved solids, total solids, nitrate, chloride, total bacterial count and total coliform count using standard laboratory techniques. Mean values of results obtained were compared with regulatory standards for drinking water by World Health Organization (WHO). Analysis of variance was used to test if there is more variance between the samples than within them. The results revealed high variation between the WHO standards and the obtained values from well water samples. With the exception of $\mathrm{pH}$ that fall within the range, the values for total hardness, total dissolved solid, DO, nitrate, chloride and conductivity fall below, while the values for temperature, $B O D$, bacteria count and coliform count are above the WHO standards. The study therefore recommends that wells should be sited at least 30m away from a possible source of contamination while the surrounding environment should be kept clean and tidy to avoid or reduce contamination.
\end{abstract}

Key Words: Well water, Quality, Parameters, WHO standards, Zaria

\section{Introduction}

Water is one of the most essential elements that nature provides to sustain life of plants, animals and man. Water is used for a variety of purposes, and in varying quantity, quality, and timing characteristics. It is a fundamental natural resource that influences human health, ecology and economic development. Water is used in many ways to benefit mankind and his environment for growing food and domestic uses; tourism and cultural purposes and it plays crucial role in sustaining the earth ecosystem (Market al., 2002). According to Annan (2003), potable water is precious, we cannot live without it and human activities have profound impact on the quality and quantity of available water. It has been argued that gradual reduction

*Corresponding Author: Yakubu, S.

Email: samuel.yakubu@uniosun.edu.ng 
Water Quality Assessment of Hand-Dug Well in Sabon-Gari, Zaria.................YAKUBU et al.

over time in the quality and/or quantity of fresh water can add to the instability of a region by depleting the health of a population, obstructing economic development, and exacerbating larger conflicts (Postel and Wolf, 2001).

Globally, 1.1 billion people do not have access to adequate and potable water supply; 460 million people are currently suffering acute water shortage while 2.4 billion people are lacking adequate sanitary facilities (Jidauna et al., 2013). It has been estimated that $97 \%$ of water on the earth's surface is salt water and only $3 \%$ is fresh; slightly over two thirds of the fresh water is frozen in glaciers and polar ice caps while the remaining unfrozen fresh water is found mainly as groundwater, with only a small fraction present above the ground or in the air (Molden, 2007; Chartres and Varma, 2010).

Water is classified under two main categories based on its location and these are surface and underground water (Appelo and Posma, 2005). But contrary to the widely held theoretical view of groundwater being the "safest'" water, wells are found to be polluted in terms of the physical, chemical and microbiological composition.

Groundwater constitutes the largest source of dug-well water. It is located below the soil surface and largely contained in interstices of bedrocks, sands, gravels, and other interspaces through which precipitation infiltrates and percolates into the underground aquifers due to gravity. A major way of groundwater abstraction for use is by means of hand-dug well. A well is an excavation or structure created in the ground aquifers. According to Huisman (1986), it is a hole or a shaft sunk into the earth for the purpose of obtaining water and other fluid from an underground supply. Such hole can be constructed in different ways upon which wells are commonly classified as hand-dug, borehole, among others. The hand-dug well water is drawn by a pump, or using containers such as rubber or iron buckets that are raised by hand. Wells can vary greatly in depth, water volume and may require treatment to soften the water contained in them.

In Nigeria, hand-dug well is a major source of groundwater abstraction for domestic water supply in the urban centers. The increase demand for fresh water coupled with limited supply of pipe-borne water has forced urban dwellers to resort to the use of well water for drinking and other domestic purposes. Today, over $70 \%$ of the population use hand-dug wells to satisfy their water needs (Ashano and Dibal, 2006; Yakubu, 2013). The hand-dug wells are in most cases situated in unsanitary locations. Water from hand-dug wells is rarely analyzed nor treated before use. Until recently, most artificial wells in the country do not have pump. The hand dug-wells are usually between 10-20m deep depending on the geological characteristics of the area, and are lined with stones, bricks and recently cemented rings (Ajibade, 2014).

Issues relating to water quality in Nigeria have been the subject of many studies (Gideon, 1999; Edema and Fapetu, 2001; Adediji and Ajibade, 2005; Ashano and Dibal, 2006; Folorunsho, 2010; Yakubu and Baba, 2010; Jidauna et al., 2013; Yakubu, 2013; Ajibade, 2014; Oyetayo et al., 2015 among others). Contrary to the widely held theoretical view of groundwater being the "safest" 
water, wells are found to be polluted in terms of temperature, mineral contents, organic matter and bacterial concentration among others. The quality of groundwater is determined by testing various parameters of interest. The results are compared with the standard qualities required for water intended for human consumption and use (Appelo and Posma, 2005). This is so because unsafe drinking water contributes to numerous health problems in developing countries such as the one billion or more incidents of diarrhoea that occur annually (Mark et al., 2002; Yakubu and Baba, 2010). Contaminants such as bacteria, viruses, heavy metals, nitrates and salt have polluted water supplies as a result of inadequate treatment and disposal of waste from humans and livestock, industrial discharges, and over-use of limited water resources (Singh and Mosley, 2003).

Shallow wells of different sizes, depths and widths have been sunk in the study area for potable water supply. Water consumed plays a key role in determining the physical, mental and social health of any one (Yakubu and Baba, 2010; Yakubu, 2013).

The need to assess the quality of water from hand-dug well consumed by the public at Sabon-Gari, Zaria becomes imperative because it has a direct effect on the health of individuals.

\section{Study Area}

The study area is Zaria in Kaduna State which lies between latitudes $11^{\circ}$ $07^{\prime} \mathrm{N}$ and $12^{\circ} 00^{\prime} \mathrm{N}$, and between longitudes $07^{\circ} 44^{\prime} \mathrm{E}$ and $8^{\circ} 00^{\prime} \mathrm{E}$ (Fig 1). It is about $80 \mathrm{~km}$ from Kaduna (the state capital). Zaria lies at a height of about $700 \mathrm{~m}$ above sea level and is part of the Hausa High Plains of northern Nigeria.
The area falls within the tropical wet-dry climate and experiences two distinct seasons namely: the wet and dry seasons which are caused by the movement of the Inter-Tropical Discontinuity (ITD) under the influence of two major air masses namely the tropical continental (cT) and the tropical maritime $(\mathrm{mT})$. The temperature is high throughout the year, with the monthly mean rising from January $\left(21^{\circ} \mathrm{C}\right)$ and attaining a maximum in April $\left(29^{\circ} \mathrm{C}\right)$. A decade mean annual temperature (1999-2008) is $26^{\circ} \mathrm{C}$ (Yakubu, 2009). The onset of the raining season in the study area is usually May June and by July - August its influence covers almost every parts of the country. Zaria has a mean annual rainfall of about $900 \mathrm{~mm}$ which supports savanna vegetation.

The geology of the study area is part of the Basement complex rocks, the plains attain elevation ranging from about $550 \mathrm{~m}$ to $740 \mathrm{~m}$ asl and are underlain by pre-cambrian rocks of variable composition. This area was described as undifferentiated Basement Complex (FDALR, 1990).

The landforms consist of inselbergs, pediment landscape overlying the basement complex nearly level of gently undulating plain (FDALR, 1990), and broad stream valleys. The seasonal vegetation cover in the area and occasional intensive rainfall combined to give rise to wide spread sheet wash.

The major soil type of the study area is tropical ferruginous; while along the wide gentle sloping valleys are the dark vertisol and fadama soils. The area falls within the guinea savanna region and therefore most of the vegetation have been degraded due to human interference ranging from agriculture, wood 
harvesting, overgrazing, urbanization processes etc. The true climatic climax vegetation is almost absent except in the outskirts especially in the southern suburb. The topographical nature of the area is a gentle rolling undulating landscape with residual hills of various sizes and shapes and is drains largely by three channels. These include rivers Galma, Kubani and Saye.

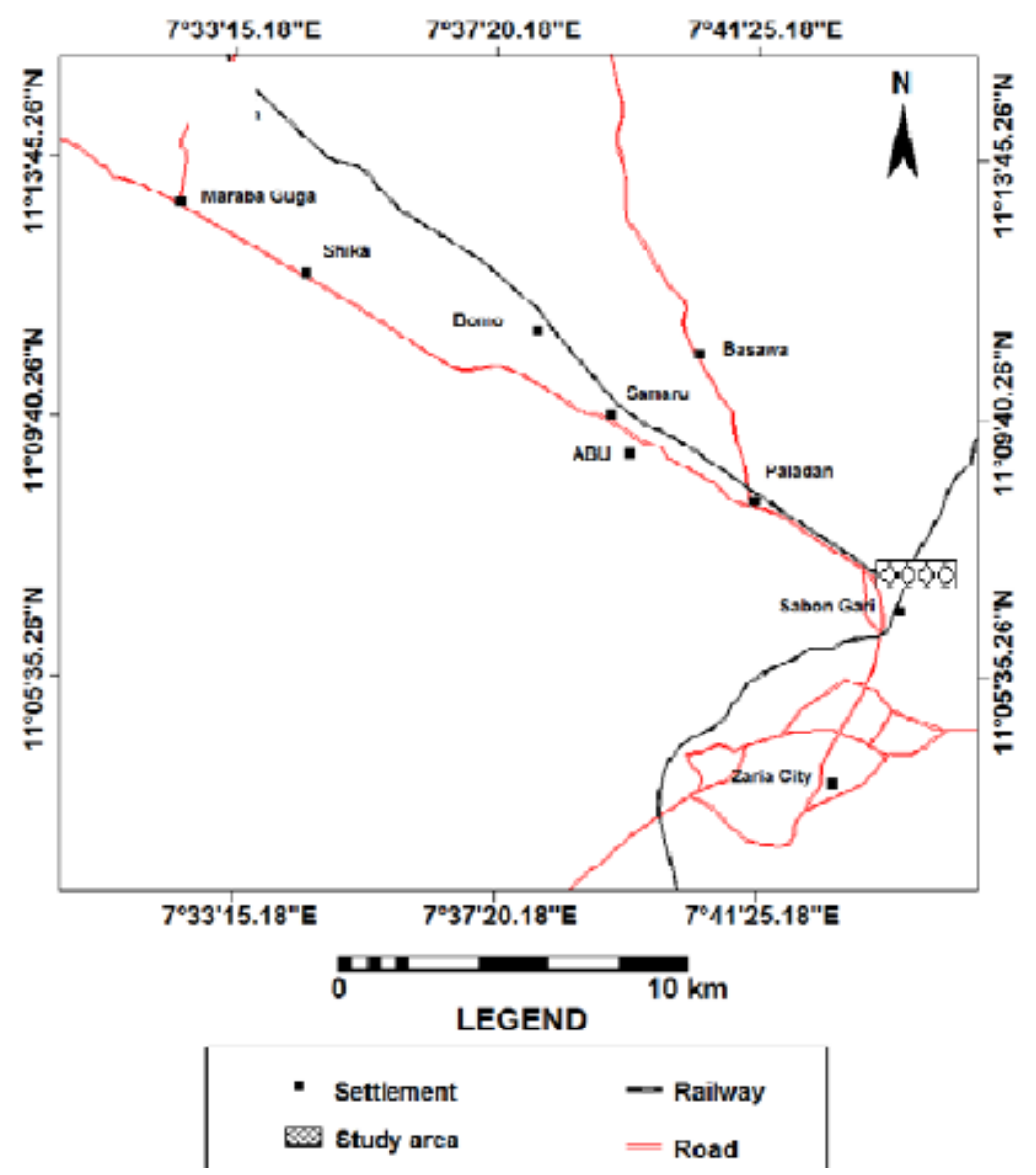

Fig. 1: Map of Zaria Showing the Study Area

\section{Materials and Methods Sample Collection}

Three sets of sampled hand dug-wells were used for the study. They are small, medium and large wells classified based on their diameter. The small wells ranged from $45.75 \mathrm{~cm}$ to $61 \mathrm{~cm}$, the medium wells ranged from $64.05 \mathrm{~cm}$ to $91.5 \mathrm{~cm}$ while the large wells ranged from $94.55 \mathrm{~cm}$ to $122 \mathrm{~cm}$ in diameter. These wells vary in depth from $10.0 \mathrm{~m}$ to $23.0 \mathrm{~m}$. The small and medium wells majorly covered household wells where in most cases a single fetcher is used to draw water. The large wells, on the other hand, are mainly the public wells which are not covered (or whose covers got damaged without replacement). Their surrounding area is usually marshy, full of litter and bushy unlike most small and medium wells while multiple fetchers are used to draw water from them. Some of these wells are seasonal in nature. 
Sampling Techniques and Data Analysis

Water samples were collected from twenty-seven (27) wells at specific locations. That is nine wells each from small, medium and large wells. Water samples were collected directly from the wells into clean polyethylene stopper bottles which have been washed with soap solution, rinsed three times with pure water and then rinsed again three times with $1 \% \mathrm{HNO}_{3}$ after which they were rinsed with the well water to be collected. The samples were taken to the laboratory and analyzed for the following parameters: $\mathrm{pH}$, temperature, dissolved oxygen biochemical oxygen demand (BOD), total hardness, dissolved solids, total solids, nitrate, chloride, conductivity total bacterial count, and total coliform count.

The experiment utilized standard laboratory techniques as described by Agbenin (1995) such as electrode for $\mathrm{pH}$ value, titration for total hardness, nitrate and chloride, separation techniques (evaporation) for dissolved solids and total solids, agar count for total bacterial count and total coliform count. Laboratory analysis of samples was carried out at the Centre for Energy Research and Training (CERT), Ahmadu Bello University, Zaria, Nigeria. Mean values of results obtained were compared with the World Health Organization (WHO) Standards to ascertain the extent of departure from or conformity with the international guidelines while Analysis of variance was used to test if there is more variance between the samples than within them.

\section{Results and Discussion}

Following the analysis of water samples from the hand dug-wells in the study area, variations in the levels of both physico-chemical and micro-biological characteristics were observed. Table 1 compares the mean values of water samples from small, medium and large wells in Sabon-Gari, Zaria while Table 2 shows the variations in terms of range, mean value of concentration of each parameter examined compared with the WHO (2004) standards.

Table 1: Mean values of water sample from small, medium and large wells

\begin{tabular}{llllllll}
\hline \multirow{2}{*}{ Parameters } & $\begin{array}{l}\text { Small } \\
\text { Wells }\end{array}$ & $\begin{array}{l}\text { Medium } \\
\text { Wells }\end{array}$ & $\begin{array}{l}\text { Large } \\
\text { Wells }\end{array}$ & $\begin{array}{l}\text { Standard } \\
\text { Deviation }\end{array}$ & \multicolumn{2}{r}{ ANOVA RESULT } \\
\cline { 6 - 8 } $\mathrm{pH}$ & 6.8 & 7.8 & 7.5 & 0.75 & 4.58 & 3.40 & $\mathrm{NS}$ \\
Temperature $\left({ }^{\circ} \mathrm{C}\right)$ & 22.7 & 24.3 & 24.8 & 1.70 & 3.09 & 3.40 & $\mathrm{~S}$ \\
Total hardness $(\mathrm{mg} / \mathrm{l})$ & 166.3 & 175.0 & 190 & 23.03 & 1.20 & 3.40 & $\mathrm{~S}$ \\
Total dissolved solid $(\mathrm{mg} / \mathrm{l})$ & 284.5 & 328.2 & 295.3 & 32.41 & 3.02 & 3.40 & $\mathrm{~S}$ \\
Dissolved oxygen $(\mathrm{mg} / \mathrm{l})$ & 2.6 & 3.2 & 2.8 & 0.37 & 13.24 & 3.40 & $\mathrm{NS}$ \\
BOD $(\mathrm{mg} / \mathrm{l})$ & 14.2 & 13.6 & 15.1 & 1.63 & 2.11 & 3.40 & $\mathrm{~S}$ \\
Nitrate $(\mathrm{mg} / \mathrm{l})$ & 3.5 & 3.7 & 3.9 & 0.51 & 1.62 & 3.40 & $\mathrm{~S}$ \\
Chloride $(\mathrm{mg} / \mathrm{l})$ & 215.4 & 220.7 & 225.4 & 9.34 & 2.27 & 3.40 & $\mathrm{~S}$ \\
Conductivity $(\mathrm{us} / \mathrm{cm})$ & 559.6 & 674.1 & 782.6 & 110.21 & 28.85 & 3.40 & $\mathrm{NS}$ \\
Bacteria count $(\mathrm{cfu} / \mathrm{ml})$ & 94.5 & 102.3 & 105.2 & 5.14 & 14.72 & 3.40 & $\mathrm{NS}$ \\
Coliform count $(\mathrm{cfu} / \mathrm{ml})$ & 9.7 & 8.5 & 10.3 & 1.7 & 2.99 & 3.40 & $\mathrm{~S}$ \\
\hline
\end{tabular}

$\mathrm{R}=$ Remarks $\quad \mathrm{NS}=$ Not Significant $\quad \mathrm{N}=$ Significant 
Table 2: Comparison of Mean Water Values with WHO (2004) Guidelines

\begin{tabular}{|c|c|c|c|c|}
\hline Parameters & $\begin{array}{l}\text { Well } \\
\text { Range }\end{array}$ & $\begin{array}{l}\text { Mean } \\
\text { Value }\end{array}$ & $\begin{array}{l}\text { WHO Standards } \\
\text { (2004) }\end{array}$ & Deviation \\
\hline $\mathrm{pH}$ & $6.1-8.4$ & 7.4 & $6.5-8.5$ & Within range \\
\hline Temperature $\left({ }^{\circ} \mathrm{C}\right)$ & $18.5-25.0$ & 23.2 & 23.5 & -0.2 \\
\hline Total hardness (mg/l) & $135.9-220.3$ & 184.6 & 500 & -312.6 \\
\hline Total dissolved solid(mg/l) & $250.6-330.3$ & 287.7 & 1000 & -716.1 \\
\hline Dissolved oxygen (mg/l) & $2.4-3.6$ & 2.9 & 5 & -2.1 \\
\hline BOD $(\mathrm{mg} / \mathrm{l})$ & $12.5-20.1$ & 14.3 & 10 & +4.3 \\
\hline Nitrate (mg/l) & $2.7-4.5$ & 3.7 & 10 & -6.3 \\
\hline Chloride (mg/l) & $205.3-236.8$ & 220.0 & 250 & -29.5 \\
\hline Conductivity (us/cm) & $528.6-834.5$ & 668.6 & 1000 & -327.7 \\
\hline Bacteria count $(\mathrm{cfu} / \mathrm{ml})$ & $98.1-110.4$ & 101.2 & 100 & +1.2 \\
\hline Coliform count $(\mathrm{cfu} / \mathrm{ml})$ & $7.0-13.1$ & 9.5 & 0 & +9.5 \\
\hline
\end{tabular}

Most of the parameters examined are higher in the large wells than in the small and medium wells as indicated in Table 1. The reason could be attributed to the unsanitary conditions of the large wells in most cases. The large wells are usually without cover with the surrounding littered with both old and fresh household wastes, unused rope, fetchers, rubber buckets and plastic bottles. It is usually marshy due to lack of drainage which makes such place a breeding ground for mosquitoes.

The results in Table 2 show that most parameters tested were either above or below the international standards with the exception of $\mathrm{pH}$, which falls within the WHO (2004) limits. The mean values for temperature, total hardness, total dissolved solid, dissolved oxygen, nitrate, chloride, and conductivity fall below the WHO standards while those for BOD, bacteria count and coliform count are above the WHO standards.

The $\mathrm{pH}$ of pure water is refers to the measure of hydrogen ions concentration in water. It ranges from 0 to 14 . In general, water with a $\mathrm{pH}$ of 7 is considered neutral while lower of it referred acidic and a $\mathrm{pH}$ greater than 7 known as basic. According to WHO standards, $\mathrm{pH}$ of water should be 6.5 to 8.5. The mean $\mathrm{pH}$ value of 7.4 obtained falls within WHO (2004) recommendation. It is noticed that water with low $\mathrm{pH}$ tends to be toxic while water with high degree of $\mathrm{pH}$ turned into bitter taste. Changes in $\mathrm{pH}$ lead to a negative impact on plant growth. High $\mathrm{pH}$ water can also reduce the efficacy of pesticides. The analysis of variance did not indicate significant differences in the $\mathrm{pH}$ level.

The mean value of temperature is $23.2^{\circ} \mathrm{C}$ which for instance is -0.2 lower than the WHO standard. Analysis of variance shows more variance between the samples than within them.

Hard water is characterized with high mineral contents that are usually not harmful for humans. It is often measured as calcium carbonate $\left(\mathrm{CaCO}_{3}\right)$ because it consist mainly calcium and carbonates the most dissolved ions in hard water. According to WHO (2004), hardness of water should be $500 \mathrm{mg} / \mathrm{l}$. From this study, mean values of hardness ranges from 135.9 - $222.7 \mathrm{mg} / \mathrm{l}$. Analysis of variance shows more variance between 
the samples than within them. These results indicated that hardness of water is in accordancewith the WHO standards and it is not harmful for local inhabitants. Therefore, the water is suitable for irrigation in terms of total hardness.

Mean values of total dissolve solid ranges from 250.6-395.3 mg/l. ANOVA indicated more variance between the samples than within them. There is no agreement reached on negative or positive effects of water that exceeds the WHO standards limit of $1,000 \mathrm{mg} / \mathrm{l}$ (Muhammad et al., 2013). Water has the ability to dissolve a wide range of inorganic and some organic minerals or salts such as potassium, calcium, sodium, bicarbonates, chlorides, magnesium, sulfates etc. These minerals produced unwanted taste and diluted color in appearance of water. Total dissolved solids in drinking water originate from sewage to urban industrial wastewater. Therefore, total dissolve solid test is considered a sign to determine the general quality of the water.

The dissolved oxygen did show significant variation by analysis of variance. It has mean value of $2.9 \mathrm{mg} / \mathrm{l}$ with a deviation of -2.1 from $\mathrm{WHO}$ standard value of $5 \mathrm{mg} / \mathrm{l}$ (WHO, 2004). The values obtained for BOD ranged from 12.3 - $20.1 \mathrm{mg} / \mathrm{l}$ with mean value of $14.3 \mathrm{mg} / \mathrm{l}$. This value is high compared to the WHO standards value of $10 \mathrm{mg} / \mathrm{l}$. Analysis of variance shows more variance between the samples than within them. Nitrate is one of the most important diseases causing parameters of water quality particularly blue baby syndrome in infants. The sources of nitrate are nitrogen cycle, industrial waste, nitrogenous fertilizers etc. The WHO allows maximum permissible limit of nitrate in drinking water is $10 \mathrm{mg} / \mathrm{l}$. In this study, result clearly showed that the concentration of nitrate ranges from 2.7 $4.5 \mathrm{mg} / 1$ with mean of $3.7 \mathrm{mg} / \mathrm{l}$. Analysis of variance indicated significant difference among the wells. This result indicates that the quantity of nitrate in study sites is acceptable and may not pose threat on the health of inhabitants. The presence of nitrate helps in determining the level and effect of faecal pollution of the water especially on the growing infants and pregnant women (Adekunle et al., 2007; Yakubu, 2013). Most of the nitrate found in water was due to organic matter, mainly of animal origin.

Chloride is mainly obtained from the dissolution of salts of hydrochloric acid as table salt $(\mathrm{NaCl}), \mathrm{NaCO} 2$ and added through industrial waste, sewage, sea water etc. Surface water bodies often have low concentration of chlorides as compare to ground water. It has key importance for metabolism activity in human body and other main physiological processes. High chloride concentration damage metallic pipes and structure as well as harm growing plants. According to WHO standards concentration of chloride should not exceed $250 \mathrm{mg} / \mathrm{l}$. Although the values of 205.3-236.8 $\mathrm{mg} / \mathrm{l}$ obtained in this study are within the WHO standards, all the wells have high concentration of chloride. Difference among the different well by analysis of variance is significant.

While conductivity has mean value of $672.3 \mathrm{us} / \mathrm{cm}$ with a deviation of -327.7 from WHO while difference among the different well by analysis of variance is not significant. 
Both bacteria count and coliform count recorded higher mean values of $101.2 \mathrm{cfu} / \mathrm{ml}$ and $9.5 \mathrm{cfu} / \mathrm{ml}$ with deviation of +1.2 and +9.5 respectively above the WHO standards. The difference among the different wells by analysis of variance is not statistically significant for bacteria count while that of coliform is statistically significant. The high values of bacteria count and coliform count could be attributed to the fact that the wells, especially the public ones, are not protected, most times without lids and concrete linings, while the surrounding is always marshy, littered with municipal, solid, or faecal wastes.

The guideline values for un-piped water supplies $(0$ fecal coliform organisms per $100 \mathrm{ml})$, WHO recommends that coliform organisms should not occur repeatedly (WHO, 2004). However, this level cannot be reached without a treatment of the water. To simplify the interpretation of the high counts measured in open wells of developing countries, Feachem (1980), proposed a division into three categories corresponding to the relative quality of the water: $>100$ fecal coliforms $/ 100 \mathrm{ml}$ should be considered satisfactory; between 100 and 1000 col./100 ml suggests a strong contamination and risks to health; and above $1000 \mathrm{col} . / 100 \mathrm{ml}$, the water should be considered seriously pathogenic.

The pronounced presence of bacteria and coliform in water samples indicate contamination by human or animal wastes. These pathogens may pose a special health risk for infants, young children and people with severely compromised immune systems (USEPA, 2002).
Groundwater is a relatively safe source of potable water compared with other unprotected water sources e.g. rivers, springs, rain water. Water samples taken directly from hand-dug wells in this study contained levels of coliform above the WHO. This result is similar to the findings of the study undertaken by John et al. (2014) and Asadu et al. (2015).

From field observation, the high contamination of water samples observed in the selected wells could be attributed to the indiscriminate dumping of refuse around most of the wells, which could leach down from the surface. Studies, such as Folorunsho's (2010) and Yakubu's (2013) have revealed that distance from refuse dumps is not the only factor responsible for the level of concentration of pollutants in wells. Other factors such as geologic material developed on the poorly weathered crystalline basement complex rocks, poor drainage and sewage systems, discharge from industries and application of fertilizers could also be responsible for the level of pollution in the well water. The health risk with manifesting symptoms of acute toxicity is only associated with known exposure and or ingestion. Heavy metals reaching toxic levels have health associated risks and some of the associated symptoms are experienced by some consumers and it is an indication that ill-health affect efficiency in one way or the other (Yakubu and Baba, 2010). This is because most hand-dug wells are sited in unsanitary locations like refuse dumps, suck-away, pit latrines, near drainage channels, abattoirs among others. 


\section{Conclusion and Recommendations}

Water is a fundamental part of our life. Given that it is an essential and indispensable resource for human existence, there is need to ensure that it exists in high quality. Although, most of the substances determined are naturally found in water, the primary aim in assessing water quality is to ensure that they do not exceed levels which are likely to be of concern to human health. It appears that poor well maintenance is the main factor contributing to the water pollution/contamination in the study area.

To avoid further pollution/contamination problem of wells in the study area, there must be enforcement of standards for location, construction and operation of wells while the surrounding environment should be kept clean and tidy. Disinfection of well water by chlorination and continuous monitoring to determine any change in the level of pollution at the sources are also recommended. More so, each well should have its own fetcher that will be used by everybody.

\section{References}

Adediji, A. and Ajibade. L.T. (2005). Quality of Well Water in Ede Area, South-western Nigeria. Journal of Human Ecology, 17(3): 223-228.

Adekunle, I.M., Adetunji, M.T., Gbadebo, A.M. and Banjoko, O.A. (2007). Assessment of groundwater quality in a typical rural settlement in southwest Nigeria.Int. $J$. Environ. Public Health, 4: 307-318. DOI: 10.3390/ijerph 20070 4040007.

Agbenin, J.O. (1995). Laboratory Manual for Soil and Plant Analysis. Department of Soil Science, Faculty of Agriculture / Institute for Agricultural Research, Ahmadu Bello University, Zaria, Nigeria.

Ajibade, LT. (2014). Physico-Chemical and Biological characteristics of Hand Dug Wells Water in Ilorin Metropolis, Nigeria. The Nigerian Geographical Journal, 9(2): 146162.

Annan, K. (2003). On: World Water Day. Special United Nation Report.

Appelo, C.A.J. and Posma, D.C. (2005). Geochemistry of Groundwater and Pollution. Published by Balkema, Leiden.

Asadu, A.N., Daniya, T.S., Ofuyah, W.N. and Edemivwaye, O.J. (2015). Water Quality Assessment of HandDug Wells in Agbarho, Delta State, Nigeria. International Journal for Research in Emerging Science and Technology, 2(6): E-ISSN: 23497610.

Ashano, E.N. and Dibal, H.U. (2006). Groundwater quality of Jos Metropolis. Journal of Environmental Sciences, 8(2): 5057.

Chartres, C. and Varma, S. (2010). Out of water. From Abundance to Scarcity and How to Solve the World's Water Problems FT Press (USA), 2010.

Edema, M.O. and Fapetu, O.M. (2001). Micro-Biological and PhysicoChemical Analysis of different sources of drinking Water in Abeokuta, Nigeria. Microbial, 15: 57-61.

Feachem, R.G. (1980). Bacterial standards for drinking water quality in developing countries. The Lancet August. 2, 255 - 256. 
Federal Department of Agriculture and Land resources (FDALR) (1990). Field Soil Survey. Fed. Dept. of Agric, and Land Resources Kaduna; Nigeria.

Folorunsho, J.O. (2010). An assessment of the quality of water in shallow wells in Sabon-Gari, Zaria. Kaduna State. The Zaria Geographer, 18(1): 71-82.

Gideon, R.K.(1999). An Assessment of Current Level of Pollution of Handdug wells in SamaruZaria. Unpublished Dissertation, Department of Geography, Ahmadu Bello University Zaria, Nig.

Huisman, L. (1986). Lecture Note on Ground Water Recovery, Belgrade Yugoslavia, art B 8-3-8-4.

Jidauna, G.G., Dabi, D; Saidu; Abaje, J.B.B.and Ndabula, C. (2013). Assessment of Well Water Quality in Selected Locations in Jos, Plateau State, Nigeria. International Journal of Marine, Atmosphere Earth Science, 1(1): 38-46.

John, Y.M., Kareem, S.A., Kefas, H.M. and Polycarp, A. (2014). Quality Assessment of Hand-Dug Well in Hongtown. International Journal of Scientific Research Engineering \& Technology (IJSRET), 3(2): 306-311, ISSN $2278-0882$.

Mark, W.R., Ximing Cai and Sarah, A.C. (2002). World Water and Food to 2025: Dealing with Scarcity. International Food Policy Research Institute, NW, Washington, DC, USA.

Molden, D. (ed.) (2007). Water for food, Water for life: A Comprehensive Assessment of Water Management in Agriculture. Earthscan/IWMI.

Muhammad, M., Samira, S., Faryal, A. and Farrukh, J. (2013). Assessment of Drinking Water Quality and its Impact on Residents Health in
Bahawalpur City. International Journal of Humanities and Social Science, 3(15): 114-128.

Oyetayo, K.T., Songu, G.A., Amos, G.A., Ndabula, C. and Jideuna, G.G. (2015). Spatial variation in Hand-dug Well Water contamination by effluents from Wukari Abbatoir, Wukari, Taraba State, Nigeria. Nigerian Geographical Journal, 10(2): 126-143.

Postel, S.L. and Wolf, A.T. (2001). Dehydrating Conflict. Foreign Policy. 126. 60-67.

Singh, I.S. and Mosley, L.M. (2003). Trace metal levels in drinking water on Viti Levu, Fiji Islands. S. Pac. J. Nat. Sci. 21:31-40.

Yakubu, S. (2013). Assessment of water quality of hand-dug wells in Zaria LGA, Kaduna State, Nigeria. The International Journal of Engineering and Sciences (IJES), 2(11): 01-04.

Yakubu, S. (2009). Effects of municipal soil waste application on soil properties and crop qualities in Zaria urban area northern Nigeria. Unpublished PhD. Thesis, Dept of Geog. University of Abuja.

Yakubu, S. and Baba, B. (2010). Assessment of water quality consumed by students and its health implications on their academic performance.Journal of Studies in Science and Mathematics Education, 1(1): 103-111.

USEPA (2002). Methods for Measuring the Acute Toxicity of Effluents and Receiving Water for Freshwater and Marine. Retrieved on 20-04-2012 from www.cala.ca/allo-Toxicityreferen

World Health Organization (WHO) (2004). Guidelines for Drinking Water quality. Geneva. Vol. 1(3). 